\title{
The Value and Quality Factors Influencing Purchase Decision of Car Audio Customers
}

\author{
${ }^{1}$ Piyaporn Thongmool \& ${ }^{2}$ Senee Puangyanee
}

\begin{abstract}
This study examined the value and quality factors affecting the purchase decision of the car audio customers in Phra Nakhon Si Ayutthaya Province. Quantitative data were gathered from 385 selected customers of the product through purposive sampling method. The Pearson's correlation coefficient using multiple regressions was employed for data analysis. The results revealed that the customers consider the product value factors in their purchase of car audio at high level while product quality factors at the highest level. In terms of product value, the price and social value influenced the purchase decision while the emotional value has no influence. In terms of quality, the service performance, durability, and additional functions influenced the purchase decision while reliability has no influence. The results of the study are helpful to the companies as fundamental data to their business planning in improving their products and services to meet the needs and demands of their customers.
\end{abstract}

Keywords:

value, quality, service performance, durability, additional functions, car audio product, purchase decision

Suggested Citation: Piyaporn Thongmool \& Senee Puangyanee (2021). The Value and Quality Factors Influencing Purchase Decision of Car Audio Customers. International Journal of Academe and Industry Research, Volume 2, Issue 1, pp. 1- 20.

About the authors:

${ }^{1}$ Corresponding author. Professor, Faculty of Business Administration and Information Technology, Rajamangala University of Technology, Suvarnabhumi, Thailand

${ }^{2}$ Professor, Faculty of Business Administration and Information Technology, Rajamangala University of Technology, Suvarnabhumi, Thailand 


\section{Introduction}

The majority of the domestic travel in Thailand, around the metropolitan and nearby provinces such as Phra Nakhon Si Ayutthaya, Angthong, Suphanburi, and Saraburee is by car. The long drive within the countryside creates new demand for car audio products as a form of class and entertainment. These products have come highly desirable for all car drivers and passengers as the most indispensable device for listening to the news, music, and watching TV during the travel.

These types of products involve various specifications and functionalities. They can be directly connected with smartphone and other devices to perform various functions including music, movie, and GPRS. As such, it brings convenience to the drivers and passengers during short and long travels around the country. As a result, the market trend of the car audio industry is likely to increase (Siam Business Online, 2013). However, the customers nowadays are getting picky and consider different factors related to the product and their personal satisfaction. If these companies are able to produce products with high value to consumers, this will successfully lead to purchase decision and will create high profits (Kotler, Floh, \& Zauner, 2011). There are two considerations for customers' purchase decision which include product value and quality. If these kind of products are of good quality and durability, these qualities can create customers' satisfaction and purchase decision at the same time (Crosby, 1979).

The valuation of car audio products consists of price, product, emotional and social aspects while the factors considered for quality consist of product performance, reliability, durability, and service performance. These factors are highly considered by majority of the customers in almost all product purchase. Any of these factors can motivate a customer to spend money on the products. However, each customer requires a different purchase priority in which companies must consider to meet the common customer needs. Through meeting the common needs of the customers, companies become better competitors and gain competitive advantage in the market. In 2020, the automobile industry and car audio industry experienced a slow turnout due to the COVID-19 pandemic. This was accompanied by the downtrend in the purchase activities of the consumers. According to Krungsi research, it is 
expected that the automobile sales will grow by $3-4 \%$ on average in 2021 - 2022. Although the sales of car audio industry have dropped due to the pandemic, the sales of the automobile industry increased (Siam Business Online, 2021). Accordingly, this trend could mean customers who bought their previous cars were likely to replace them by 2020 - 2022. In addition, auto industry operators are planning to launch more than 20 new models to stimulate demand from the car market. This surely will boost the manufacture and sale of the car audio industry as they plan to meet the needs of the automobile market (Siam Business Online, 2021).

Relative to the current and future trends in the automobile industry, this study aims to investigate the different value and quality factors affecting the purchase decisions of the car audio customers in Phra Nakhon Si Ayutthaya Province. Specifically, the indicators of product value are price, product, emotion and social factors. In addition, the quality factors are product performance, reliability, durability, additional functions, and service performance.

The research questions and hypotheses are as follows:

Research Question 1: To what extent the value of the product affects the purchase decision of the car audio customers in Phra Nakhon Si Ayutthaya Province?

H1: Price value positively affects purchase decision of car audio customers.

H2: Product value positively affects purchase decision of car audio customers.

H3: Emotional value positively affects purchase decision of car audio customers.

H4: Social value positively affects purchase decision of car audio customers.

Research Question 2: To what extent the quality of the product affects the purchase decision of car audio customers in Phra Nakhon Si Ayutthaya Province?

H5: Quality of product performance positively affects purchase decision of car audio customers.

H6: Quality of additional function positively affects purchase decision of car audio customers. 
H7: Reliability positively affects purchase decision of car audio customers.

H8: Durability positively affects purchase decision of car audio customers.

H9: Qualify of service performance positively affects purchase decision of car audio customers.

\section{Literature review}

\subsection{Product value}

According to Rust and Oliver (1994), value of the product refers to what customers perceive from purchasing products and this perception can create frequent purchase in the future. Moreover, Butz and Goodstein (1996) claimed that value of the product meant "the ability to buy a product". Carlson et al., (2015) mentioned that the value of product means what consumers get from products. Customers can compare one product with other products before making the purchase decision. For this, Kotler et al., (2011) identified composition of product's value that customers look into in four dimensions including price value, product value, emotional value, and social values. These four dimensions can influence consumer purchase decisions. If companies are able to deliver value to their customers, they can create a competitive advantage in the market. The purchase emotion ties up between customer's satisfaction and quality of products.

In terms of the car audio companies, Putnuan (2019) explained that the value of the product reflects the desire of the customer for the products and services that these companies

offer placing highest value to the criteria and preferences of the customers. For this, the companies should build confidence in order to win the customers in buying the products and availing the services that sets them apart and different than their competitors. This also can get the customers' attention and improve customers' perceptions of the products and services. If this trend goes up, it will eventually help generate sales and create high profit, thus improving the market share (Putnuan 2019). The car audio companies need to consider product management to enable customers to get value from the products or services rather than getting the same value from the competitors in the market. 


\subsection{Product quality}

Product quality refers to the ability of the products to meet the performance measures and requirements set for the ultimate customers' satisfaction (Crosby, 1979). Quality of products make customers agree to pay the price with full satisfaction. Companies clearly know that customers would buy products with good quality. Although high quality of products is different from the each of the customers' perspective, majority of them consider the durability as a primary test of product quality. This can also include flexibility of the products. Some products can be integrated with other technologies such as mobile phones and smartphones which customers can customize and update the programs or applications.

According to Garvin (1987), the quality of product includes eight fundamental characteristics such as performance, complementary function, reliability, compliance with required standards, durability, serviceability, aesthetic, and reputation. Customers decide to buy products that meet their needs and satisfactions. Somboonthavee et al. (2018) pointed out that the quality of product is an outcome of operational efficiency that produces the required quality. It consists of functions, reliability, durability, serviceability, aesthetic, and the reputation. Pangariya, S. and Sawang, S. (2018) added that the quality of product has five dimensions that includes performance, appearance, feature, reliability, durability, and fit and finish.

\subsection{Purchase decision}

Purchase decision refers to the thinking process from identifying a need and satisfying customers to choose a specific product or brand (Chaiwat, 2008). According to Phuphani (2012), consumers' purchase decision can be classified and categorized accordingly as familiarity decisions, limited decisions, and wide decisions. When it comes to the purchase decision, customers stop searching for and evaluating alternative products from other groups of products. After they know which product or brand they want to buy, they then make decision to purchase.

Prasetya \& Sianturi, (2019) claimed that the purchase decision is based on the perceived quality of the product, the perceived fair price quality and the customer 
satisfaction. In addition, Kladsap (2019) argued that the purchase decision is a product of careful study and information search on the perceived consumer problems. As such, customers find information from alternative evaluations in order to decide to purchase products or not.

From the foregoing review of the literature, the study conceptual framework was drawn from the various concepts discussed. The framework shows the variables as independent and dependent.

\section{Figure1}

Conceptual framework of the study

\begin{tabular}{|l|l|}
\hline $\begin{array}{l}\text { Value of product } \\
\text { - Price value } \\
\text { - Product value } \\
\text { - Emotional value } \\
\text { - Social value }\end{array}$ & \multicolumn{1}{|c|}{$\begin{array}{c}\text { Purchase } \\
\text { decision of car } \\
\text { audio products }\end{array}$} \\
$\begin{array}{l}\text { Quality of product } \\
\text { - Product performance } \\
\text { - Additional functions } \\
\text { - Reliability } \\
\text { - Durability } \\
\text { - Service performance }\end{array}$ & \\
\cline { 2 - 2 }
\end{tabular}

\section{Methodology}

\subsection{Research approach}

This study employed quantitative method in the collection and analysis of the data. The quantitative data gathered were using inferential statistics to test the different hypotheses. 


\subsection{Sample size}

The samples were the 385 selected car audio customers in Phra Nakhon Si Ayutthaya Province using the purposive sampling methods. Customers that have already purchased and were intending to purchase car audio products within the location were targeted for investigation. To get the sample size from the total population, the study determined the sample size using the W.G. Cochran by setting the $95 \%$ confidence level and $5 \%$ tolerance level (Wongkittiwat, 2016, page 74). A total of 385 samples were estimated.

The demographic characteristics of the samples include:

Gender: $260(67.50 \%)$ male and $125(32.50 \%)$ female.

Age: 26 - 35 years old $(255,66.20 \%) ; 16$ - 25 years old $(72,18.70 \%) ; 46$ years old and over $(26,6.80 \%)$

Employment: public companies (264, 68.60\%), business owners (77, 20\%), government officers $(25,6.50 \%)$, other occupations $(19,4.90 \%)$

Average monthly income: 15,001-25,000 Baht (173 (44.90\%); 25,001-35,000 Baht $(107,27.80 \%)$; 35,001 Baht or more $(79,20.50 \%)$; less than 15,000 Baht $(26,6.80 \%)$.

Preferred brand: Pioneer (104, 27\%); Panasonic (81, 21\%); Alpine (41, 10.60\%); Sony (36, 9.40\%); Kenwood (25, 6.50\%); Bose (19, 4.90\%); Herman (12, 3.1\%); Other brands $(67,17.40 \%)$.

\subsection{Research instrument}

The research instrument for this study was a set of self-designed questionnaire. Questions were divided into four sections. The first part was about the general information of respondents that includes age, education, career, and income. The second part was on the respondents' assessment of the factors associated with the value of the product that consist of price, value, emotion and social. In the third section, respondents were asked about their

opinions of the product quality that includes factors such as performance, functionality, 
reliability, durability and serviceability. The last section was relevant to the customer decision to purchase the car audio products.

\subsection{Data reliability and collection}

Data reliability was performed with 30 samples using Cronbach's Alpha to measure the confidence of each question. The questionnaire had to be no less than 0.7 (Nunnally \& Bernstein, 1994). All questions were found to be between $0.82-0.87$ which is greater than 0.7 . The set of questionnaire has been validated for content validity by a qualified person to find the consistency index between the question and the objective (Item Objective Congruence Index: IOC) with the corresponding number should be greater than 0.50 (Vanichbancha, 2018). Thus, this study screened the questions for validity.

\subsection{Data analysis}

The data were analysed using the descriptive statistics including frequency and percentages as well as inferential statistics through the multiple regression analysis method. The inferential statistics tested the hypotheses relating to the product value, product quality, and purchase decision.

\section{Findings and Discussion}

\subsection{Findings}

Table1 shows the overall value of product with a high extent of influence (Mean = $4.2, \mathrm{SD}=0.62$ ). The product value and emotional value were the highest extent at mean value 4.23 and $4.27(\mathrm{SD}=0.73)$, followed by price value (mean $=4.19, \mathrm{SD}=0.68)$, and social value $($ mean $=4.11$, S.D. $=0.72)$. 


\section{Table1}

The extent of the product value factors' influence on customer purchase decision

\begin{tabular}{|c|c|c|c|}
\hline Factors & "Mean & 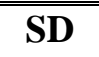 & "Descriptive Results \\
\hline Price value & 4.19 & 0.68 & High Extent \\
\hline Product value & 4.23 & 0.73 & Highest Extent \\
\hline Emotional value & 4.27 & 0.73 & Highest Extent \\
\hline Social value & 4.11 & 0.72 & High Extent \\
\hline Average & 4.20 & 0.62 & High Extent \\
\hline
\end{tabular}

Table 2 presents the overall quality of product with a high extent of influence (mean $=4.25, \mathrm{SD}=0.71)$. The quality of durability has the highest extent, at mean value $=4.39$, $\mathrm{SD}=0.74$, followed by quality of product performance and service performance (mean $=4.28$, $\mathrm{SD}=0.75$ and 0.71 , quality of reliability (mean $=4.22, \mathrm{SD}=0.71$ ), and quality of additional functions (mean $=4.02, \mathrm{SD}=0.92)$.

\section{Table 2}

The extent of the product quality factors' influence on customer purchase decision

\begin{tabular}{lccl}
\hline \hline \multicolumn{1}{c}{ Quality of Product } & Mean & SD & Descriptive Results \\
\hline Quality of product performance & 4.28 & 0.75 & Highest Extent \\
Quality of additional functions & 4.02 & 0.92 & High Extent \\
Quality of reliability & 4.22 & 0.71 & Highest Extent \\
Quality of durability & 4.39 & 0.74 & Highest Extent \\
Quality of service performance & 4.28 & 0.71 & Highest Extent \\
\hline Average & 4.25 & 0.71 & Highest Extent \\
\hline \hline
\end{tabular}


Table 3

Factors considered on the purchase decision

\begin{tabular}{lccc}
\hline \hline \multicolumn{1}{c}{ Indicators } & Mean & SD & Descriptive Results \\
\hline $\begin{array}{l}\text { You feel satisfied in your car audio that can be used } \\
\text { very well. }\end{array}$ & 4.32 & 0.71 & Highest Extent \\
$\begin{array}{l}\text { In making purchase decisions, you have always } \\
\text { compared the quality of each brand of products first. }\end{array}$ & 4.41 & 0.81 & Highest Extent \\
$\begin{array}{l}\text { You made the decision to purchase a car stereo from } \\
\text { obtaining enough product information. }\end{array}$ & 4.28 & 0.89 & Highest Extent \\
\hline Average & $\mathbf{4 . 3 4}$ & $\mathbf{0 . 7 4}$ & Highest Extent \\
\hline
\end{tabular}

In Table 3, the opinion on the overall purchase decision was at the highest extent $($ mean $=4.34$, S.D. $=0.74)$. The respondents indicated that they have always compared the quality of each brand of products first $($ mean= 4.41, S.D. $=0.81)$. They also identified that they feel satisfied with their car audio that can be used very worthwhile (mean=4.32, S.D. $=$ 0.71). The lowest extent of influence on the purchase decision was that that they were deciding to buy car audios based on obtaining enough product information (mean= 4.28, S.D. $=0.89$ ).

\section{Table 4}

Product value affecting purchase decision of car audio customers

\begin{tabular}{|c|c|c|c|c|c|}
\hline \multirow[t]{2}{*}{ Value of product } & \multicolumn{2}{|c|}{$\begin{array}{l}\text { Unstandardized } \\
\text { Coefficients }\end{array}$} & \multirow{2}{*}{$\begin{array}{c}\begin{array}{c}\text { Standardized } \\
\text { Coefficients }\end{array} \\
\text { Beta }\end{array}$} & \multirow[t]{2}{*}{$\bar{t}$} & \multirow[t]{2}{*}{ p-value } \\
\hline & B & Std. Error & & & \\
\hline (Constant) & 0.767 & 0.171 & & 4.477 & $0.000 * * *$ \\
\hline Price value & 0.195 & 0.057 & 0.185 & 3.396 & $0.001 * *$ \\
\hline Product vale & 0.392 & 0.053 & 0.393 & 7.415 & $0.000 * * *$ \\
\hline Emotional value & 0.061 & 0.056 & 0.061 & 1.076 & 0.283 \\
\hline Social value & 0.204 & 0.051 & 0.203 & 4.001 & $0.000 * * *$ \\
\hline \multicolumn{6}{|c|}{ Dependent Variable: purchase decision } \\
\hline $0.741, R$ Square & iust & 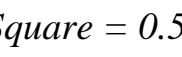 & $\mathrm{S} E E-0$ & $-W_{c}$ & $=1.921$ \\
\hline
\end{tabular}


In Table 4, the coefficient of determination of the factors price value, product value, emotional value, and social values were determined with $\mathrm{R}$ square value of 0.549 . The table shows that the independent variables were mutually described as $54.9 \%$. The price value had a significant positive effect on the decision to purchase car audios at a level of 0.05 ( $\beta=$ $0.185, \mathrm{p}<0.05)$. Thus, H1: Price value positively affects purchase decision of car audio customers was confirmed. In addition, the value of product had a positive effect on the purchase decision at the level of 0.001 ( $\beta=0.393, \mathrm{p}<0.001)$. Thus, H2: Product value positively affects purchase decision of car audio customers was accepted.

Moreover, social value also had a positive effect on the purchase decision of car audio customers at the level of 0.001 ( $\beta=0.203$, p <0.001) which affirmed H4: Social values positively affect purchase decision of car audio customers. However, emotional values did not significantly affect the purchase decision at $0.05(\beta=0.061, \mathrm{p}<0.05)$ level. Thus H3: Emotional value positively affects purchase decision of car audio customers was rejected.

\section{Table 5}

Product quality affecting the purchase decision of car audio customers

\begin{tabular}{|c|c|c|c|c|c|}
\hline \multirow[t]{2}{*}{ Quality of product } & \multicolumn{2}{|c|}{$\begin{array}{c}\text { Unstandardized } \\
\text { Coefficients }\end{array}$} & \multirow{2}{*}{$\begin{array}{c}\begin{array}{c}\text { Standardized } \\
\text { Coefficients }\end{array} \\
\text { Beta }\end{array}$} & \multirow[t]{2}{*}{$\bar{t}$} & \multirow[t]{2}{*}{ p-value } \\
\hline & B & $\begin{array}{l}\text { Std. } \\
\text { Error }\end{array}$ & & & \\
\hline (Constant) & 0.277 & 0.134 & & 2.061 & 0.040 \\
\hline Quality of product performance & 0.167 & 0.041 & 0.166 & 4.120 & $0.000 * * *$ \\
\hline Quality of additional functions & 0.170 & 0.033 & 0.216 & 5.090 & $0.000 * * *$ \\
\hline Quality of reliability & -0.028 & 0.052 & -0.027 & -0.541 & 0.589 \\
\hline Quality of durability & 0.380 & 0.044 & 0.379 & 8.637 & $0.000 * * *$ \\
\hline Quality of service performance & 0.259 & 0.046 & 0.249 & 5.615 & $0.000 * * *$ \\
\hline
\end{tabular}

Dependent Variable: Purchase decision

$R=0.862, R$ Square $=0.743$, Adjust $R$ Square $=0.740$, SEE $=0.369$, Durbin- Watson $=1.898$ 
In Table 5, the quality factors such as performance, additional functions, reliability, durability, and service performance shows an R square value of 0.743 clearly indicating that the independent variables are mutually described as $74.3 \%$. The quality of product performance had a positive effect on the purchase decision of the car audio customers at a significant level of $0.001(\beta=0.166, p<0.001)$. Thus, H5: Quality of product performance positively affects purchase decision of car audio customers was accepted. Moreover, the quality of additional function also had a positive effect on purchase decision at 0.001 ( $\beta=$ $0.216, \mathrm{p}<0.001)$ level. As a result, H6: Quality of additional function positively affects purchase decision of car audio customers was also accepted.

In addition, the quality of durability is significant at $0.001(\beta=0.379, \mathrm{p}<0.001)$ level that confirms H8: Durability positively affects purchase decision of car audio customers. It was the same level of $0.001(\beta=0.249, \mathrm{p}<0.001)$ for service quality that also confirms H9: Service performance positively affects purchase decision of car audio customers. However, reliability does not affect the purchase decision of the customers as signified by $\beta=-0.027, p$ $=0.589$. Thus, H7: Reliability positively affects purchase decision of car audio customers was rejected.

The table 6 shows the correlation coefficients between the different variables. The Pearson's correlation coefficients were employed using the multiple regression analysis conditions. It predicts the significant relations between the product value factors consisting of price value, product value, emotional value, and social value as well as the product quality factors consisting of quality of performance, quality of additional function, quality of reliability, quality of durability, and quality of service performance. The independent variables were correlated with a value of not more than 0.80 . The VIF was found less than 10, while the tolerance was shown between 0 - 1. It can be indicated that the relationship among independent variables did not create problems of Multicollinearity. Therefore, the hypotheses tested with multiple regression analysis were acceptable. 


\section{Table 6}

Correlation coefficients between variables

\begin{tabular}{|c|c|c|c|c|c|c|c|c|c|c|c|c|c|}
\hline & & 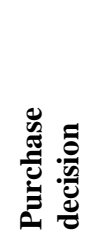 & 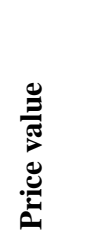 & 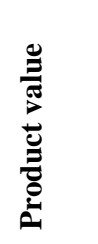 & 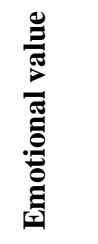 & 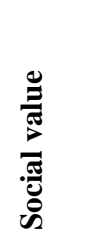 & 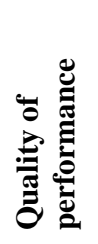 & 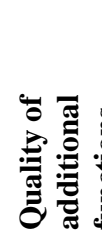 & 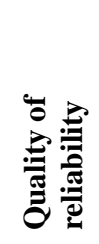 & 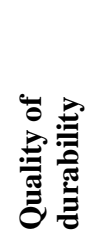 & 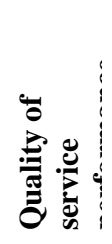 & 节 & VIF \\
\hline \multirow{10}{*}{$\begin{array}{l}\text { Pearson } \\
\text { Correlation }\end{array}$} & $\begin{array}{l}\text { Purchase } \\
\text { decision }\end{array}$ & 1.000 & & & & & & & & & & & \\
\hline & Price & 0.629 & 1.000 & & & & & & & & & 0.296 & 3.377 \\
\hline & Product & 0.687 & 0.704 & 1.000 & & & & & & & & 0.277 & 3.607 \\
\hline & Emotional & 0.591 & 0.791 & 0.671 & 1.000 & & & & & & & 0.290 & 3.443 \\
\hline & Social & 0.606 & 0.643 & 0.667 & 0.662 & 1.000 & & & & & & 0.316 & 3.169 \\
\hline & Performance & 0.741 & 0.683 & 0.761 & 0.624 & 0.579 & 1.000 & & & & & 0.281 & 3.555 \\
\hline & $\begin{array}{l}\text { Additional } \\
\text { functions }\end{array}$ & 0.723 & 0.643 & 0.730 & 0.647 & 0.681 & 0.706 & 1.000 & & & & 0.308 & 3.248 \\
\hline & Reliability & 0.732 & 0.682 & 0.632 & 0.715 & 0.746 & 0.701 & 0.757 & 1.000 & & & 0.193 & 5.185 \\
\hline & Durability & 0.799 & 0.611 & 0.600 & 0.659 & 0.491 & 0.682 & 0.654 & 0.766 & 1.000 & & 0.290 & 3.447 \\
\hline & $\begin{array}{l}\text { Service } \\
\text { performance }\end{array}$ & 0.769 & 0.622 & 0.572 & 0.612 & 0.587 & 0.712 & 0.657 & 0.760 & 0.738 & 1.000 & 0.321 & 3.117 \\
\hline
\end{tabular}

\subsection{Discussion}

This study examined the value and quality of products affecting the purchase decision of the car audio customers in Phra Nakhon Si Ayutthaya Province. From the investigation consisting of 385 samples, the sample group between 26 and 35 years old with an average monthly income between 15,001 and 25,000 Baht prefer the Pioneer brand of the car audio products.

With regards to research question 1 on the extent the value of the product affects the purchase decision of the car audio customers in Phra Nakhon Si Ayutthaya Province; the results revealed that price value positively affects purchase decision of car audio customers (H1). The price of car audio products was a major concern of the customers. They are looking for benefits from products and they make comparisons with the other competitors in the market. The results were consistent with the study of Djatmiko and Pradana (2015) that the reasonable price of the product had an effect on the purchase decision of a Samsung smartphone. According to Kotler et al. (2011), the value the consumers look into making 
purchase decisions was based on reasonable prices. If customers found that the price was suitable for the product, customers then decide to buy. Quality of product with fair prices enables customers to purchase with satisfaction at the same time (Prasetya \& Sianturi, 2019).

For the value of product, the results confirmed that it positively affects purchase decision of car audio customers (H2). If the product can perform its quality functions including an easy-to-use method, this can respond to the daily life of consumers which can induce them to buy the product. The results were consistent with the study of Wongkittiwat (2016) that the value of the product cost-effectiveness reflect on the easy-to-use process which affect the consumers' decision to buy electric cars during work days in Bangkok. According to Kotler et al. (2011), consumers perceive the benefits of a product when it is capable of performing its duties at a good quality. This prods consumers to consider buying the product. Moreover, customers also consider buy a product that meets their needs and satisfactions (Somboonthavee et al. 2018).

The quantitative results rejected the $\mathrm{H} 3$ : Emotional value positively affects purchase decision of car audio customers. The samples indicated that emotional value has no influence on their purchase decision of car audio products. The inconsistencies lie on the individual differences. Although customers look at the same products, different customers can have different thoughts, attitudes, buying patterns and moods. However, the current study shows that these have no effect on their purchase decisions. This is also inconsistent with the findings of Asshidin et al. (2015) that the emotional value influences consumer purchase decisions. Arguably, when consumers are satisfied with their previous purchase experience, they will still decide to buy the same product and brand. For this, the companies should build the product confidence among its customers so that they will repeat the purchase (Putnuan 2019). The results clearly established the fact that the consumers nowadays are not into impulsive buying when it comes to car audio products. As this product is an specialty product that requires prior investigation of its features and functionalities, the surveyed customers do not prefer impulsive buying patter. These customers are not buying the product based on emotional appeal and product marketing strategies.

The results affirmed $\mathrm{H} 4$ that social values positively affect purchase decision of car audio customers. It is clearly establishing a trend that these customers are buying car audio 
products for social validation, prestige and some bragging rights due to the product brand or quality. They want to create a good image among their friends. In particular specifications of the car audio products, the respondents were also considering the products with a beautiful exterior design and delicate look to add additional appearance and visual presence. The results were consistent with the study of Chalermchai (2014) that social value was a factor in deciding to buy luxury cars among the population of Samut Prakan Province in Thailand. The majority of customers value the look, elegant design and classy look which are validated by the people around them. Products good performance together with appearance, feature, reliability, durability, and fit and finish satisfy the consumers and motivate them in making purchase decision (Pangariya \& Sawang, 2018).

With regards to research question 2 on the extent the quality of the product affects the purchase decision of car audio customers in Phra Nakhon Si Ayutthaya Province; the results revealed that the quality of product performance positively affects purchase decision of car audio customers (H5). Since the car audio products can be used with clear picture and sound, the specifications and the expected performance meet the customer needs as reflected by the survey results. In addition, the products can be installed in accordance with the operational standards preferred by the customers. The results were consistent with the study of Chanchamyai (2013) that the engine performance factor affects the purchase decision of the used cars from agency tents. Most customers decided to buy used cars because the engine can be used efficiently. It was also consistent with the study of Wachirasrisirikul (2012) that the performance of the product affect the consumers' purchase decision of cars through Honda dealerships in Phitsanulok Province, Thailand. It was also found that the performance of the motorcycles affect the consumers' purchase decision. The customers decide to buy the product based on the performance of the cars' engines. As it was enumerated that there are five dimensions of performance that include appearance, feature, reliability, durability, and fit and finish, which satisfy customers' needs (Pangariya, S. and Sawang, S. 2018). Similarly, Somboonthavee et al. (2018) also claimed that performance is measured through efficient operation that meets required quality.

The results also confirmed $\mathrm{H} 6$ that the quality of additional function positively affects the purchase decision of car audio customers. The customers look for extra from the product; 
they need to get additional functionalities and features that would compensate the price. The additional functions equate and justify the product price tempting customers to spend extra price for it. For instance, a remote control, touch screen, and voice control had a positive impact on the buying considerations of the customers. This was consistent with the study of Somboonthawee et al. (2018), that the quality of additional functions affect purchase decision of Japanese car in Bangkok, Thailand. Customers decide to buy Japanese cars with various accessories that facilitate car interior for both drivers and passengers comfort and relaxation.

However, reliability has no effect on the purchase decision of car audio customers (H7). The respondents indicated they had a very good understanding of the car audio products including the modern technology. The customers' knowledge establishes their credibility in inspecting the specifications and functions of the product. As the customers have the credibility in choosing the right product, the reliability of the product was not a consideration when they buy. The results argued the study of Somboonthawee et al.,(2018) that product reliability affect the purchase decision of Japanese cars in Bangkok, Thailand. This meant that Japanese cars did not have any problems during the warranty period.

The results were support to $\mathrm{H} 8$ that durability positively affecting purchase decision of car audio customers. The durability of car audio products created purchase decision of the customers. If the products were not easily broken or damaged and it can be used for a long time without any technical problems, customers would love to spend money for it. And if the products did not need to be repaired often, it positively affected the purchase decision of car audio customers in Phra Nakhon Si Ayutthaya Province. The results were consistent with the study of Somboonthawee et al.,(2018) that quality of durability influenced the purchase decision of Japanese cars in Bangkok. With Japanese cars, customers made purchase decision because it did not cause technical problems in which it did need to be repaired often.

The results also affirmed H9 that service performance positively affects purchase decision of car audio customers. The service performance of car audio products facilitates customers' long-term use and maintenance of the products. If the cost of maintenance was not too expensive, this positively drove purchase decision. In addition, customers also preferred less time for maintenance, friendly services, and caring repair from sellers. The results were consistent with the study of Somboonthawee et al., (2018) that a quick service 
would make consumers to quickly purchase the products. In another study, the level of factors influencing the purchase decision of used cars were the ease of maintenance, easy to find spare parts, and cheap prices (Thananukulchai, 2011).

\section{Conclusion}

This study examined the value and quality of products affecting purchase decision of the car audio customers in Phra Nakhon Si Ayutthaya Province in Thailand. The factors indicating value of product which consist of price, product, and social, positively affected the purchase decisions of the customers. This is the major consideration of the respondents when looking for car audio coupled with the product value and social value. They want to see how product can perform its functions with their cars. Further, the social value gives customers the good image and social status. However, emotional value has no effect on their purchase decision. When customers are satisfied with the product quality, price, and social value, they are sure buyers of the car audio.

On the other hand, the product quality which consists of performance, durability, additional functions, and service performance, affect the customers' purchase decision. The respondents agreed that the description of a good car audio product performance include clear picture on the screen, good sound and easy to install. These are the foremost considerations when they look for the specifications and functionalities of the product. They would surely spend extra money for it. The additional functions considered by the respondents include remote control, touch screens, and voice control. These features temp them to avail it. They also look for durability of products in order to use them for longer time without any technical problems. The service performance indicators the customers look into are low-cost and less-time maintenance, friendly services, and caring repair from sellers. However, reliability has no effect on their purchase decision. With the customers' understanding and good knowledge about the car audio products, they can easily detect and prove issues related to product reliability.

The results of the study are beneficial to the car audio companies on their product planning and marketing. The basic opinion and consideration of the respondents on the 
factors affecting their purchase decision are essential to the companies in their operational decisions. As the sales trend of the product is getting uphill, companies are expected to provide ultimate customer satisfaction to keep up with the demand and needs of its clientele. Through this study, a backgrounder on customer needs and wants are identified and clarified.

This study is quantitative in nature which limits the perception and opinion of the customers through a closed-ended questionnaire. The study is also location-specific which cannot generalize the patterns and trends of purchasing behaviour of car audio customers. The number of samples may not be sufficient and the selection of sample does not include potential and probable customers of the products. With these limitations, further studies are encouraged. Researchers can employ the use of an in-depth interview, expand the number of samples, choose different locations and nationalities for cross-cultural analysis and include general consumers' perception of the product to establish strong data for analysis. The different locations such as Bangkok, Chaingmai, and Cholburi where large groups of car audio customers are located can be considered for this.

\section{References}

Asshidin, N. H. N., Abidin, N., \& Borhan, H. B. (2015). Preceived quality and emotional value that influence consumer's purchase intention towards American and local products. Paper presented at the 7th International Economices \& Business Management Conference, Malaysia.

Butz, J. H. E., \& Goodstein, L. (1996). Measuring customer value: Gaining the strategic advantage. Organizational Dynamics, 24(3), 63-77.

Carlson, J., O’Cass, A., \& Ahrholdt, D. (2015). Assessing customers' perceived value of the online channel of multichannel retailers: A two country examination. Journal of Retailing and Consumer Services, 27, 90-102.

Chaiwat, K. (2008). Advertising and marketing promotion. Bangkok: McGraw-Hill.

Chalermchai, T. (2014). Factors Influencing the Selection of Luxury Cars among Population in Samut Prakan Province. (Master of Business Administration), Graduate school Bangkok University.

Chanchamyai, W. (2013). Factors Affecting Car Purchase through Used Car Tents. (Master of Business Administration), Sripatum University.

Crosby. (1979). Three Experts on Quality Management TQLO Publication Research, 92-102. 
Djatmiko, T., \& Pradana, R. (2015). Brand Image and Product Price, Its Impact for Sumsung Smart Phone Purchase decision. Paper presented at the 3rd Global Conference on Business and Social Science (2015), Kuala Lumpur, Malaysia.

Garvin, D. A. (1987). Competing on the eight dimensions of quality. Harvard Business Review, 6(1), 101-109.

Kladasap, N. (2019). Brand Value Affecting the Buying Decision of Skin Care Cream in Oriental Princess Brand, at Central Department Store Rattanathibet Brarch, (Master of Business Administration Program), Siam University.

Kotler, P., Floh, A., \& Zauner, Z. (2011). Marketing Management Millenium Edition. Retrieved from https://www.perspectiva.md

Nunnally, J. C., \& Bernstein, I. H. (1994). The Assessment of Reliability. Psychometric Theory, 3, 248-292.

Pangkariya, S. and Sawang, S. (2018). Factors of perception of value that customers receive and quality factors. Relationships that affect Loyalty of pharmacy customers in Thailand. Economics and Business Administration Review, 14 (1), 20.

Prasetya, Y. E. \& Sianturi, J. (2019). Customer Repurchase Intention in Service Business: A

Case Study of Car Repair Service. Management and Entrepreneurship: Trends of Development, 2(8), 20.

Phuphani, W. (2012). Consumer's decision making. Retrieved from http://www.slideshare.net/kingkongzaa/consumers-decision-making-ch-11

Putnuan, S. (2019), Research Report on Marketing Strategy Development Guidelines. Suan

Sunandha Rajabhat University.

Rust, R. T., \& Oliver, R. L. (1994). Service quality: Insights and managerial implications from the frontier. New York: Sage Publications, Inc.

Siam Business Online. (2013). Annual Report Online. Retrieved from https://www.siamturakij.com/28

Siam Business Online. (2021). Monthly Report Online. Retrieved from https://www.siamturakij.com/home

Somboonthawee, K., Sriprai-ngam, K., \& Srangthin, L. (2018). Quality factors that affect the decision to buy Japanese cars Retrieved from Faculty of Management, Information Technology Campus, Phetchaburi: 
Somboonthawee, K., Sriprai-ngam, K., and Sangtang, L. (2018) .Quality factors affecting the decision to buy a Japanese car. WMS Journal of Management - Walailak University, $7(1), 1-8$.

Thananukulchai, S. (2011). Brand Image Affecting Buying Decisions of Japanese Used Motorcycles for Consumers in Bangkok. (Bachelor of Business ), Bangkok University.

Vanichbancha, K. (2018). SPSS for Windows. Computer and research Department of Statistics: Faculty of Commerce and Accountancy Chulalongkorn University, Bangkok.

Vanichbancha, K. and Wanichbancha, T. (2018). Cronbach's Alpha coefficient. Bangkok: Samlada Printing House.

Wachirasrisirikul, P. (2012). Marketing Mix Factors Affecting Consumer's Buying Decision from "Honda" Dealership, Phitsanulok Province. (Master of Business Administration ), Naresuan University.

Wongkittiwat, P. (2016). Factors Influencing Decision to Buy Electric Vehicles Working-age Consumers in Bangkok. (Master of Business Administration), Bangkok University. 